\title{
Stakeholder perceptions of offsite construction techniques: systematic review
}

\author{
Percepções de stakeholders sobre técnicas de construção \\ offsite: revisão bibliográfica sistemática
}

\section{Eduardo Werneck Senger \\ Adriana de Paula Lacerda Santos \\ Marcos Augusto Mendes Marques \\ Sérgio Scheer}

\section{I}

Abstract

$\mathrm{n}$ the past few decades, a faster uptake has been noticed for offsite construction techniques, as supported by several relevant research streams. This study focused on the perceptions of stakeholders, which is an important research field, in terms of the manifold experiences and their critical role in decision-making. The purpose of this work was to gather quantifiable information regarding benefits and barriers of offsite construction to assist in the development or improvement of tools and strategic guidelines for the decision-making process. In total, 24 papers were selected by combining the systematic review with the snowball sampling technique to survey and quantify the perceptions of 1,625 stakeholders, and to obtain 238 barrier indexes and 99 benefit indexes. A hierarchical cluster analysis was also conducted to frame 10 clusters for benefits and another 10 for barriers. In addition, a co-citation analysis was carried out to identify 7 clusters and the associated connections between them. A database was provided with barriers and benefits, ranked by their relevance to offsite construction, as well as the bibliometrics and co-citation analysis that may help choose the best-fit source/perception for the purpose of the readers.

Keywords: Offiste construction. Stakeholder perceptions. Benefits and barriers. Systematic review. Co-citation.

\section{Resumo}

Nas últimas décadas, observou-se uma aceitação mais rápida das técnicas de construção offsite, apoiadas por várias correntes de pesquisa relevantes. Este estudo concentrou-se nas percepções de stakeholders, que em função do seu papel

${ }^{1}$ Eduardo Werneck Senger ${ }^{1}$ Universidade Federal do Paraná Curitiba - PR - Brasil

${ }^{2}$ Adriana de Paula Lacerda Santos ${ }^{2}$ Universidade Federal do Paraná Curitiba - PR - Brasil

${ }^{3}$ Marcos Augusto Mendes Marques ${ }^{3}$ Universidade Federal do Paraná Curitiba - PR - Brasil

${ }^{4}$ Sérgio Scheer ${ }^{4}$ Universidade Federal do Paraná Curitiba - PR - Brasil

Recebido em 14/12/18

Aceito em 12/05/20 fundamental no processo decisório aliado à diversidade de suas experiências, caracterizam um campo importante de pesquisa.O objetivo deste trabalho foi reunir informações quantificáveis sobre os benefícios e barreiras da construção offsite para auxiliar no desenvolvimento elou aprimoramento de ferramentas e diretrizes estratégicas para o processo de tomada de decisão.Por meio de combinação entre as técnicas de Revisão Bibliográfica Sistemática e Amostragem Bola de Neve, foram selecionados 24 artigos, que totalizaram 1.625 percepções de stakeholders, 238 indicadores de barreiras e 99 indicadores de benefícios.Também foi realizada uma análise de agrupamentos para estruturar 10 grupos para beneficios e outros 10 para barreiras. Além disso, foi realizada uma análise de co-citação para identificar 7 grupos e as conexões associadas entre eles.A pesquisa resultou em um banco de dados com barreiras e benefícios da construção offsite, classificados conforme sua relevância para os stakeholders. Foram agregadas análises bibliométrica e de cocitação para auxiliar o leitor na escolha da fonte/percepção mais adequada aos seus objetivos.

Palavras-chave: Construção Offsite. Percepções de Stakeholders. Benefícios e barreiras. Revisão bibliográfica sistemática. Cocriação. 


\section{Introduction}

The concept of prefabrication is not recent, and its application has been verified even in pre-industrial construction practices. The development of such techniques, however, has not been steady throughout history, influenced by many external factors in the past centuries, such as the industrial revolution, natural disasters, and wars (GIBB, 1999). This inconsistent development led to unsuccessful experiences, as reported by Stallen, Chabannes and Steinberg (1994). However, two decades after Stallen's paper, prefabrication techniques evolved significantly owing to extensive research being conducted in several fields, encompassing issues such as the automation and process improvement (LEU; HWANG, 2002; KHALILI;CHUA, 2014), material properties (FRAGIACOMO; LUKASZEWSKA, 2013), design (TAM et al., 2015), maintenance (PAN; GIBB, 2009), cost (PAN; SIDWELL, 2011; MAO et al., 2016), sustainability (MAO et al., 2013; LI; SHEN; ALSHAWI, 2014; JAILLON; POON, 2014), health and safety (MCKAY, 2010; BIKITSHA, 2010), and others. This resulted in new perspectives that can boost the offsite construction market, with new solutions to former hindrances, as surveyed by the McGraw-Hill (2011) and MBI (MODULAR..., 2015) reports.

\section{Terms for offsite construction}

As reviewed in more depth by El-Abidi and Ghazalia (2015), a wide range of terms can be applied to describe industrialized offsite construction. In this paper, the nomenclature will be presented to justify the search strings and eventual quotes of this systematic review:

(a) offsite production (OSP), offsite manufacturing (OSM), and offsite construction (OSC) (GOODIER; GIBB, 2005);

(b) industrialized building systems (IBS) (CONSTRUCTION..., 2010);

(c) prefabrication, preassembly, modularization, and offsite fabrication (PPMOF) (O'CONNOR;

O'BRIEN; CHOI, 2014) are termed collectively as pre-work (SONG et al., 2005);

(d) special construction methods (TATUM; VANEGAS; WILLIAMS, 1987); e

(e) modern methods of construction (MMC), most of which belong to offsite techniques (KEMPTON; SYMS, 2009).

\section{Stakeholder perceptions and decision-making tools}

To restructure the decision-making process and obtain higher levels of stakeholder engagement, a series of studies were conducted based on qualitative and quantitative data collected via surveys from experienced architecture, engineering and construction (AEC) professionals and clients. Their perceptions have helped stimulate the development of tools for the decision-making process in the OSC.

Pendlebury and Gibb (2004) described the origins and stages of developing the IMMPREST toolkit. According to these authors, after the Rethinking Construction Report (EGAN, 1998) the Construction Industry Research and Information Association (CIRIA) noticed that new studies should be conducted to examine the current application and potential benefits of the standardization and pre-assembly (S\&P). As a result, new partnerships were established to generate several publications, such as the Client's Guide and Toolkit for Standardization and Pre-assembly (GIBB, 2000), which has been further improved by Gibb and Isack (2003) by collecting data regarding clients' perceived necessities and drivers.

During the workshops for toolkit improvement, it was noticed that the participants were familiar with the benefits of industrialized construction. In addition, it was also found that a new strategy could be built by identifying the disadvantageous aspects aligned with benefits. From a list of fourteen motivators and twenty constraints, a survey was conducted with a heterogeneous group of construction professionals. The authors put the constraints into four different groups, and separated the responses accordingly to propose actions to mitigate all of them (BLISMAS et al., 2005).

The IMMPREST toolkit consisted of three different tools, and each tool introduced an increasing level of details to the current project and the specific element being evaluated. One particularity of this toolkit was that it comprised softer issues such as health and safety (H\&S) and effects on management and process benefits (BLISMAS; GIBB; PASQUIRE, 2005).

Meanwhile, similar studies were also conducted in the USA. Murtaza, Fisher and Skibniewski (1993) asserted that the feasibility of modular construction depends on many variables, and therefore, the decision

348 Senger, E. W.; Santos, A. de P. L.; Marques, M. A. M.; Scheer, S. 
of modularization was not obvious. The authors proposed a computer-based framework, the MODEX, for decision-making in the initial stage of a project. Feasibility and economic analyses were performed and the proposed framework was validated by interviews with experts in the construction industry. Based on the MODEX, the Neuromodex was developed to assist the decision-making process by employing a trained neural network system, and its performance was checked by the opinions and recommendations of industry experts (MURTAZA; FISHER, 1994). Later, the PPMOF decision framework was developed by the Construction Industry Institute (CII) to incorporate a wider range of offsite building techniques. In addition to the findings from the literature, opinions from industry experts were also considered in their preliminary research, since the data were collected through interviews and field visits in leading companies. Key characteristics, as identified from the data in the pre-work industry, were essential to the development of the framework (CONSTRUCTION..., 2002a). The findings were used as the groundwork for the development of a computerized tool (CONSTRUCTION..., 2002b).

Many subsequent works have followed this research stream with new emerging approaches, such as the prefabrication strategy selection methodology - PSSM (LUO, 2008) and the construction method selection model - CMSM (CHEN; OKUDAN; RILEY, 2010a). Given the reported relevance between the stakeholder perceptions for developing tools and the decision-making process, we reviewed papers that employed survey methods to collect data of industry stakeholder perceptions on OSC. The aim of this paper was to simplify the development process of new strategies and decision-making tools, and to provide guidelines for a proper implementation of OSC methods.

\section{Research method}

In this research, the systematic review (SR) approach was adopted by following three main steps:
(a) input;
(b) processing; and
(c) output.

\section{Input}

In this study, we identified four relevant online databases for conducting preliminary searches:
(a) Science Direct;
(b) Periódicos CAPES;
(c) Taylor \& Francis Online; and
(d) Scopus.

For each database, eight terms related to OSC were used as the search strings (Group 1) to investigate their relevance. The second group was created with thirteen terms that were essential to the decision-making process. Groups 1 and 2 were then coupled with the "AND" connector, where the terms in each group were enclosed in double quotes for an exact match, and were connected to each other with the "OR" connector, as shown in Table 1.

To be selected, the document had to be a research paper with perceptions collected from stakeholders with previous experiences in industrialization of building systems. The content can be based on literature review, but had to be written in English with stakeholders' surveys on drivers, barriers, and/or critical factors that can affect the decision-making process for OSC. These perceptions also had to be distinguished according to their positive or negative connotations.

\section{Processing}

The search procedure, which comprised of five actions, was repeated for all four databases to produce the final body of the reviewed papers, as outlined by the roadmap in Figure 1. First, the defined search string (Table 1) was applied to the fields of all documents, refined by the content type and language. When the number of the discovered documents was greater than 100, a new search was performed only for topics, that is, paper title, abstract, and keywords. The number of each search was registered in a worksheet and named "1st screening." The third action consisted of reading all titles and abstracts of the selected papers and deciding whether they should be proceeded to the next stage termed "2nd screening." For the fourth action, 
all papers were speed read, and could be discarded or selected again for the next phase, which belonged to the first batch of the reviewed papers in this case.

To elucidate the last action, it is essential to understand the basics of the "snowball sampling" concept. Goodman (1961) discussed its implications from a statistical perspective, in which each individual of a given sample was asked to designate a number of new individuals to the population. The same proposition was made for the new individuals and so on, hence the term "snowball sampling." In the present study, the authors adapted this concept and conducted a new search for every reviewed paper using its list of references as the database. This process created a loop that was only stopped when no applicable papers could be added.

Table 1 - Search strings

\begin{tabular}{|c|c|c|}
\hline Group 1 & Connector & Group 2 \\
\hline "Offsite Production" & \multirow{13}{*}{ AND } & "Advantage" \\
\hline "Offsite Fabrication" & & "Driver" \\
\hline "Preassembly" & & "Constraint" \\
\hline "Offsite & & "Disadvantage" \\
\hline Construction" & & "Barrier" \\
\hline "Offsite & & "Opportunities" \\
\hline Manufacturing" & & "Perception" \\
\hline \multirow{2}{*}{ "Prefabrication" } & & "Critical Factors" \\
\hline & & "Benefit" \\
\hline \multirow{2}{*}{$\begin{array}{l}\text { "Modern Methods of } \\
\text { Construction" }\end{array}$} & & "Requirements" \\
\hline & & "Expectation" \\
\hline \multirow{2}{*}{ "Industrialization" } & & "Hindrance" \\
\hline & & "Challenge" \\
\hline
\end{tabular}

Figure 1 - Search procedures

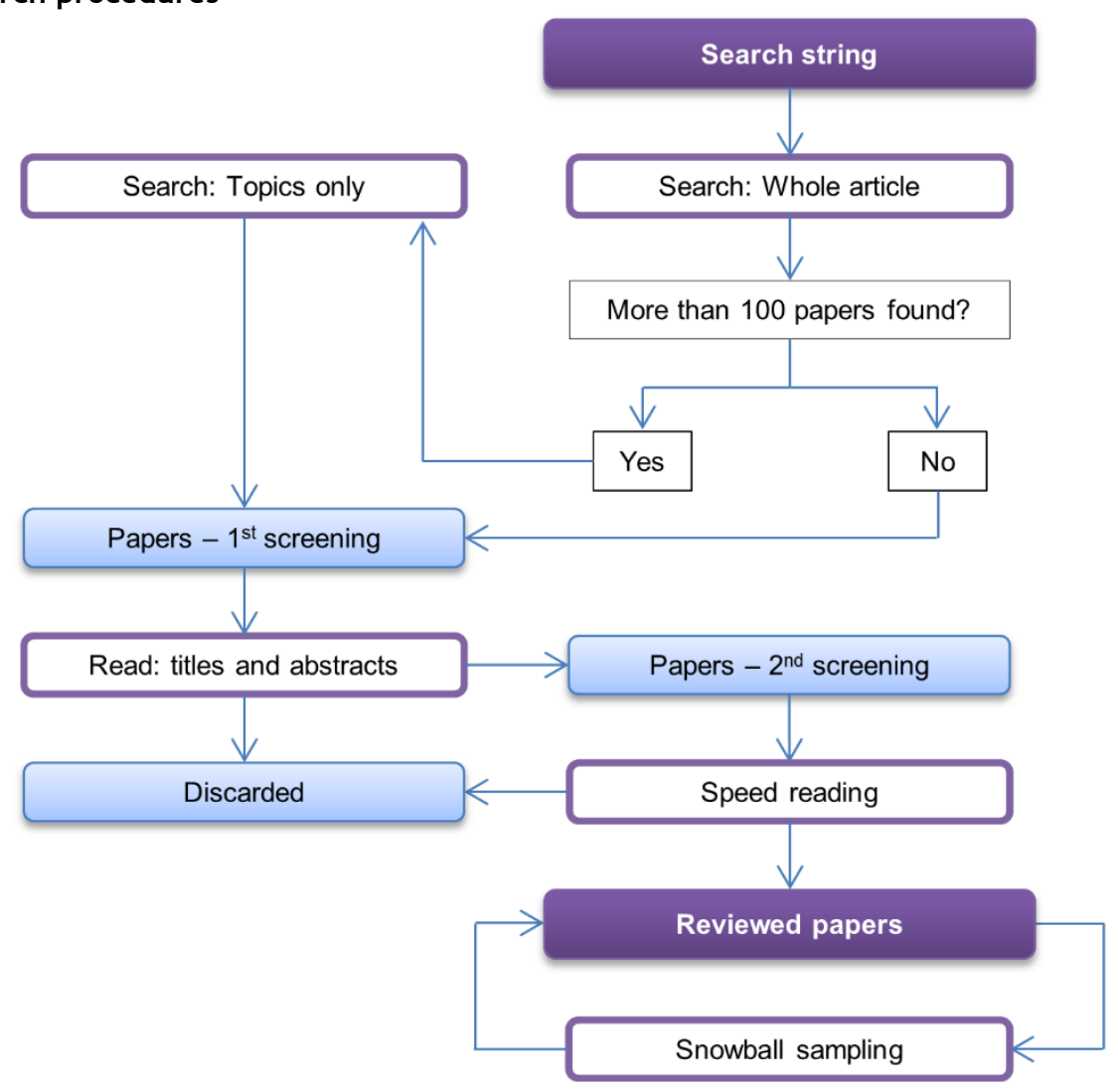

350 Senger, E. W.; Santos, A. de P. L.; Marques, M. A. M.; Scheer, S. 


\section{Output}

\section{Bibliometrics review}

The bibliometrics review seeks to encompass most of the aspects related to measuring the impact of the reviewed papers, in terms of guiding the reader by supplying general, specific, long-term, and immediate information. As depicted in Figure 2, four categories of the analysis were addressed, including the author level bibliometrics, paper-level altmetrics, traditional journal metrics, and journal level altmetrics.

Initially, the general characteristics of the selected documents were compiled, such as titles, authors, the publication year, the most-frequent keywords, journals, the number of citations, and the total sums of affiliations, journals, and studies per country. Where available, the year-based evolution of the citation count was also compiled to obtain the output rate of citations per year and a graphical disposition of the research stream progression over time.

To obtain the relationship between the reviewed papers, the authors adopted a form of document coupling named co-citation, which was defined by Small (1973) as "the frequency with which two documents are cited together." A spreadsheet was developed to extract the names of all cited authors and to create a cocitation matrix with the corresponding linkages, by disregarding the coupling of the repeated authors (e.g., situations where author A appears more than once in the same reference list). Then, the data were exported to the graphic platform Gephi 0.9.1, which allowed the visualization of the links and the clusters where different researchers were inserted. The chosen graphic layout algorithm was Force Atlas 2, which is forcedirected and thus, can create movements of repulsion and attraction, and can converge to a balanced state to assist data interpretation (JACOMY et al., 2014). Each node in the graph corresponded to one author/entity and its size was set to be proportional to the degree of interaction. The statistical concept of modularity was applied to identify and analyze the communities within the networks using the method proposed by Blondel et al. (2008), which can return a "scalar value between -1 and 1 that measures the density of links inside communities as compared to links between communities," where an absolute value close to 1 means that all edges are within communities. The average clustering coefficient was calculated to identify the network cliquishness, that is, how likely the neighbors of a given node are connected to each other. The value ranges from 0 to 1 , and 1 means that the neighbors of a given node are all connected.

In addition to the co-citation analysis, author profiles from both the reviewed and cited documents were obtained from Scopus. As a complement to the number of documents and citations, the h-index was also listed. This index was defined by Hirsch (2005) as the "number of papers with citation number $\geq h$, as a useful index to characterize the scientific output of a researcher."

Figure 2 - Measure of impact

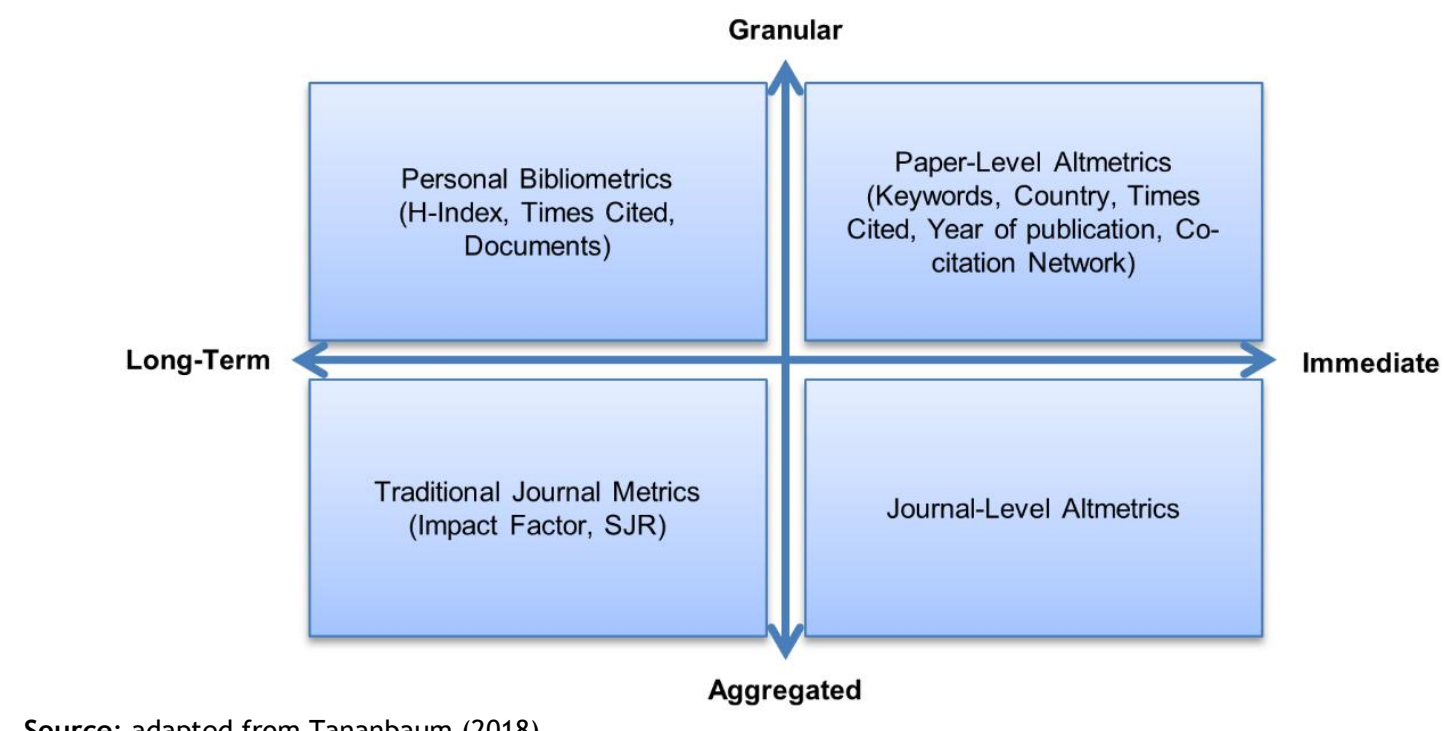

Source: adapted from Tananbaum (2018). 
Before the second group of discussion, one last bibliometric analysis was proposed, that is, the journal-level metrics. Both traditional impact analysis and altmetrics were gathered from Scopus Journal Metrics and Eigenfactor Project websites, as well as from the Journal Citation Report (JCR) 2018 and the SCImago Journal Rank (SJR) 2017. We did not intend to discuss their validity and suitability or explain them in detail, as they were largely debated in the literature (FALAGAS et al., 2008; BORNMANN et al., 2011; CANTÍN; MUNOZZ; ROA, 2015). However, by listing the main data of the reviewed documents, the authors expected them to aid in the interpretation of the impact of each document.

\section{Content review}

All the paper content was carefully examined with the aid of a computer-assisted qualitative data analysis software (CAQDAS) QDA Miner Lite ${ }^{\mathrm{TM}}$. The coding was structured to improve the reflexivity of researchers, as noted by Woods, Macklin and Lewis (2015). Four groups of data were extracted and the associated methodology, sampling size, and stakeholder perceptions were discussed.

By the means of questionnaire surveys, the researchers extracted the stakeholder perceptions and transformed their qualitative point of view into indexes. This was achieved by designing questions using the Likert scale, which usually consists of five possible answers indicating the level at which the respondent agrees or disagrees (BABBIE, 1999). However, in the reviewed studies, the content of each answer varied and therefore, had to be calibrated. A standard structure was adopted as the reference, where the highest level of agreement corresponded to five, the highest level of disagreement corresponded to one, and three meant a neutral opinion on the subject.

All factors and their indexes were tabulated into three different spreadsheets, one for benefits/motivators, one for barriers/restrictions, and the other for critical success factors. The latter will not be discussed in this paper due to the small sample size. Then, we created different categories for each factor (e.g., time, cost, quality, etc.) and grouped those with identical or similar meanings.

The indexes were then statistically processed. First, the mean values and simple count of each factor were processed. Next, a hierarchical cluster analysis was performed using the distance matrix of indexes of each paper. The calculation of the distance matrix was based on a dissimilarity measure called Euclidean distance. More specifically, in this study, we considered a single dimension $(p=1)$ provided by the indexes obtained through the Likert scale in each reviewed paper.

The clusters were created through a single linkage hierarchical method, in other words, the closest neighbors were clustered (with shorter Euclidian distances). Such a method can be defined as agglomerative, given that each object starts from its own cluster, and as they begin pairing up with closer neighbors, a bigger cluster will be formed (HAIR et al., 1998). With the software Statistica ${ }^{\mathrm{TM}}$, the interval between 2 and 20 clusters was analyzed.

\section{Results and analysis}

For the first screening, 674 documents were assembled. It was found that only one database had less than 100 results for the "all fields" search, while all the other databases exceeded 1000 results. As shown in Table 2, after expanding the restrictions to the "topics" search, the body of papers was reduced to a more applicable sample. Then, all 674 documents went through the stage where titles and abstracts were read. A total of 57 papers met both the purpose and inclusion criteria described for the SR. In these papers, 14 of them appeared more than once, and therefore had to be discarded, while the remaining 43 eligible papers were transferred to the speed-reading stage. Then, 19 papers were selected to be reviewed and after the first snowball sampling round, five more were added. Moreover, three conference papers were found in the snowball sampling, but had to be discarded due to their similarity with a part of the reviewed papers that were already published by journals. The iteration was halted when there was no work in the next snowball round that met the purpose, and the final number of papers to be reviewed was found to be 24 .

\section{Bibliometrics analysis}

\section{Paper and personal metrics}

The results can clearly demonstrate the initial stage of such a research stream as all the studies were published within the past fifteen years to the date of the search, with most of them published in the past ten years. It was also noteworthy that from the seven studies published until 2007, six occurred in the UK, with 
Tam et al. (2007) as the first study overseas. In addition, this study was conducted by considering a distinct and very specific attribute, that is, the need to reduce waste generation in construction. The initial dominance of British papers was related to the governmental movement towards S\&P as described previously. Nonetheless, as shown in Figure 3, more recent studies expanded the number of the surveyed nations, leading to new centers that include the USA (20.0\%), Malaysia (20.0\%), and China (16.7\%). Sweden and Australia also appeared in one-off studies. Although new countries were surveyed, the publications were still concentrated in the USA and the UK, which gathered more than $80 \%$ of all journals. No studies were conducted/published in neither South/Central America nor Africa. Finally, a greater spraying of nations was found by examining the author affiliations.

Construction, prefabrication, and offsite were considered to be the top three keywords, and 1,239 citations were registered by Scopus for the reviewed papers. The graphical evolution of the citations per year (Figure 4) indicated that the dissemination of the issue started after 2004 and grown at a mean pace of $56 \%$ each year. Since 2015, the citation count per year was more than tripled, showing the relevance between the papers and their research topics. Over the last decade, three papers showed the highest average citation per year in the Scopus database:

(a) Chen, Okudan and Riley (2010b) with 15.56 cites/year;

(b) Jailon, Poon and Chiang (2009) with 15.10 cites/year; and

(c) Tam et al. (2007) with 15.08 cites/year.

Three papers were distinctively relevant to more than fifty citations each:

(a) Gibb and Isack (2003) with 131 citations;

(b) Pan, Gibb and Dainty (2007) with113 citations;

(c) Blismas and Wakefield (2009) with85;

(d) Goodier and Gibb (2007) with 83; and

(e) Pan, Gibb and Dainty (2008) with 72.

The two most active authors were the British Professor Alistair Gibb and by the Australian Professor Nick Blismas, who authored seven (29.2\%) and three (12.5\%) of all published papers, respectively.

The second analysis started with the identification of all 802 authors/entities, with 1,665 citations for the reviewed papers. Table 3 presents the 9 authors/entities that appeared 15 or more times in the reference lists and together, they represented $16.6 \%$ (276) of the total citations. Note that the interpretation of the h-index was related to a specific context. Czarnecki, Kaźmierkowski and Rogalski (2013) analyzed the average hindex value for full professors in various science communities, and obtained an average h-index of 10 for the civil engineering discipline. This showed the relevance between the researchers involved in the authorship of the reviewed papers and the cited documents. In the latter, eight researchers had h-index values equal to or higher than 10, with the highest value at 50.

Next, the co-citation matrix was created, and the data were exported as a csv. file to Gephi 0.9.1, in which a directed graph with 802 nodes and 79,376 edges was generated. Seven communities can be distinguished from the graphic network overview (Figure 5) according to the modularity algorithm with an optimal score of 0.497 , indicating the existence of links both inside communities and between communities. The number of nodes (i.e., authors/entities) in each community ranged from 28 to 171. The largest conglomerate of highly cited authors, which was found inside Community 2 surrounded by other communities, acted as an external connector. It was also noticed that Community 6 and a few groups within Communities 4 and 3 had less links to the central nodes. Within Community 4, a few authors/entities were in between the communities and can be interpreted as important players for the connection to a larger set of studies. Finally, the average clustering coefficient was found to be 0.895 , which indicated a high probability for a given author to have links between all its co-cited authors.

\section{Journal metrics}

In this study, all 24 papers were published in 15 journals. The journal Construction Management and Economics gathered the biggest quantity of published papers of 5 publications; 5 journals published 2 papers; and the other nine journals had only 1 publication. The essential metrics can be found in Table 5. The journals Building and Environment, Automation in Construction, and Waste Management demonstrated similar metrics and were ranked at the top. Only seven journals were listed in the JCR 2017, and six of them 
had the Impact Factor (IF), Eigenfactor (EF), and Article Influence (AI). These journals had also the most relevant metrics among the sample and were the only journals with SJR greater than 1.0 (Table 4).

Table 2 - 1st and 2 nd screening results

\begin{tabular}{l|c|c|c|c|c}
\hline \multicolumn{1}{c|}{ Search step } & Science Direct & Periódicos CAPES & Tandfonline & Scopus & Selected \\
\hline 1st screening - All fields & 2,472 & 94 & 1,074 & 1,434 & 674 \\
1st screening - Topics & 93 & - & 27 & 460 & 43 \\
2nd screening & 14 & $8+4^{\mathrm{a}}$ & $8+2^{\mathrm{a}}$ & $13+8^{\mathrm{a}}$ & 43 \\
\hline
\end{tabular}

Note: ${ }^{\text {arepeated papers. }}$

Figure 3 - Data regarding country information of the reviewed papers
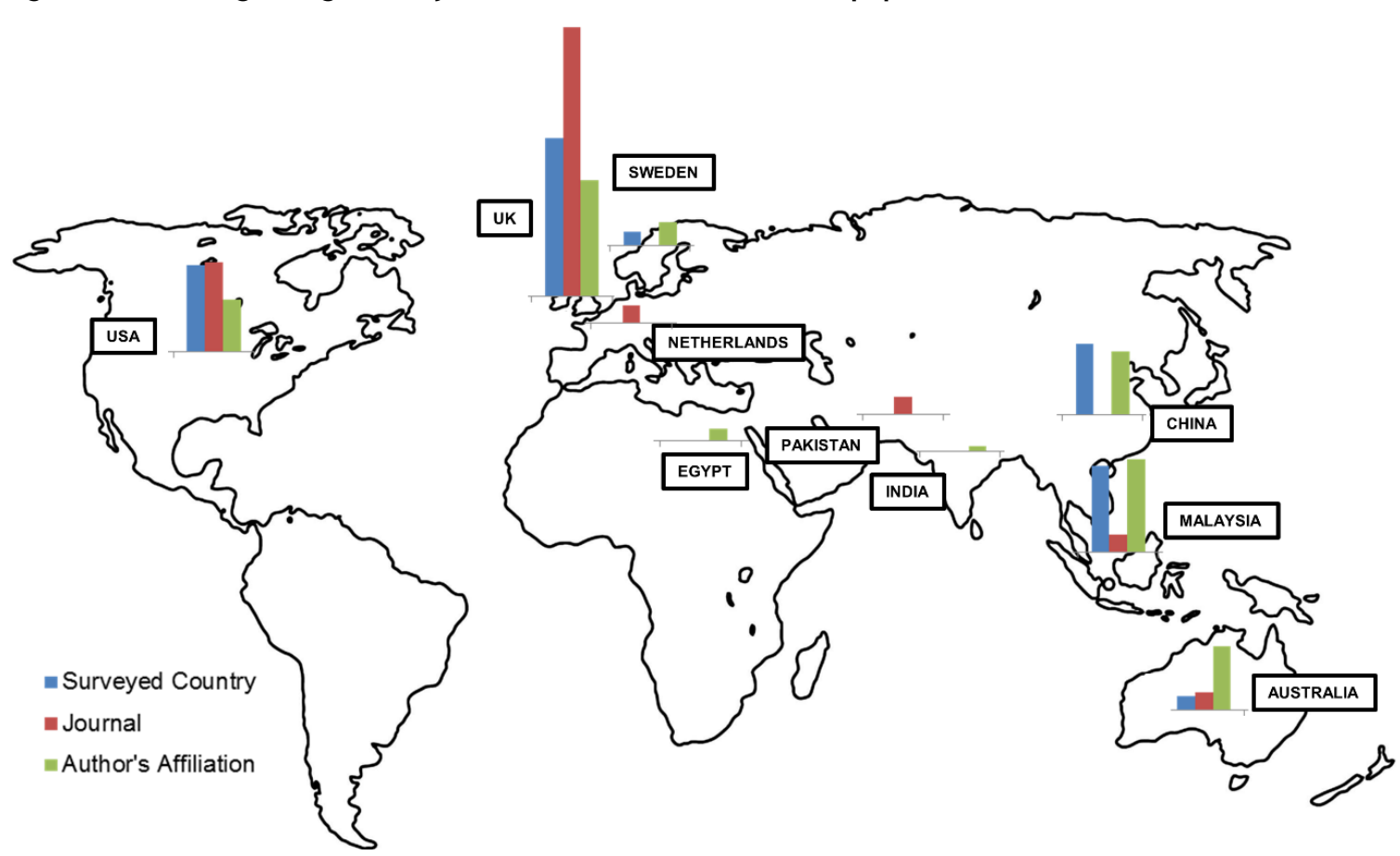

Figure 4 - SR's reviewed papers citation count per year - Scopus database

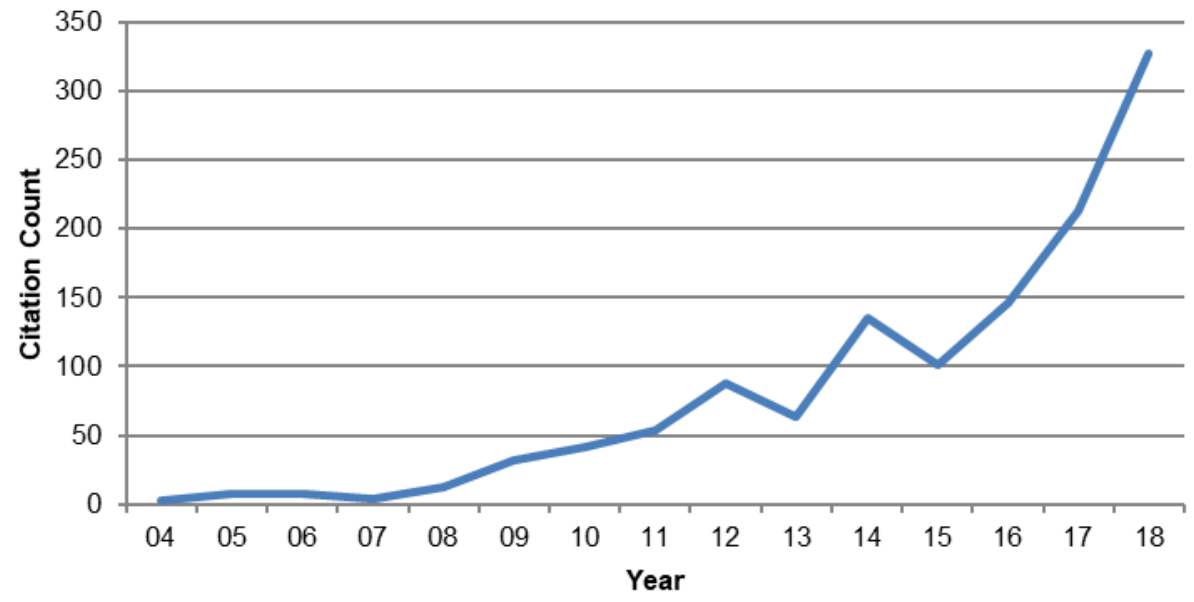


Table 3 - Most cited authors / entities

\begin{tabular}{l|c|c|c|c|c|c}
\hline \multirow{2}{*}{ Author / Entity } & \multicolumn{3}{|c|}{ Sample citations } & \multicolumn{3}{c}{ SCOPUS Author's profile } \\
\cline { 2 - 7 } & Count & \% from total & Accum. \% & Documents & Times Cited & H-Index \\
\hline Gibb, A.G.F. & 102 & 6.13 & 6.13 & 114 & 1379 & 21 \\
Pasquire, C.L. & 31 & 1.86 & 7.99 & 65 & 354 & 10 \\
Blismas, N.G. & 30 & 1.80 & 9.79 & 46 & 413 & 13 \\
Dainty, A.R.J. & 27 & 1.62 & 11.41 & 242 & 3080 & 31 \\
Poon, C.S. & 20 & 1.20 & 12.61 & 275 & 8448 & 50 \\
Goodier, C.I. & 19 & 1.14 & 13.75 & 80 & 515 & 12 \\
Jaillon, L. & 17 & 1.02 & 14.77 & 9 & 354 & 7 \\
Gann, D. & 15 & 0.90 & 15.68 & 56 & 3034 & 22 \\
Pan, W. & 15 & 0.90 & 16.58 & 60 & 393 & 11 \\
\hline
\end{tabular}

Figure 5 - Graphic network overview

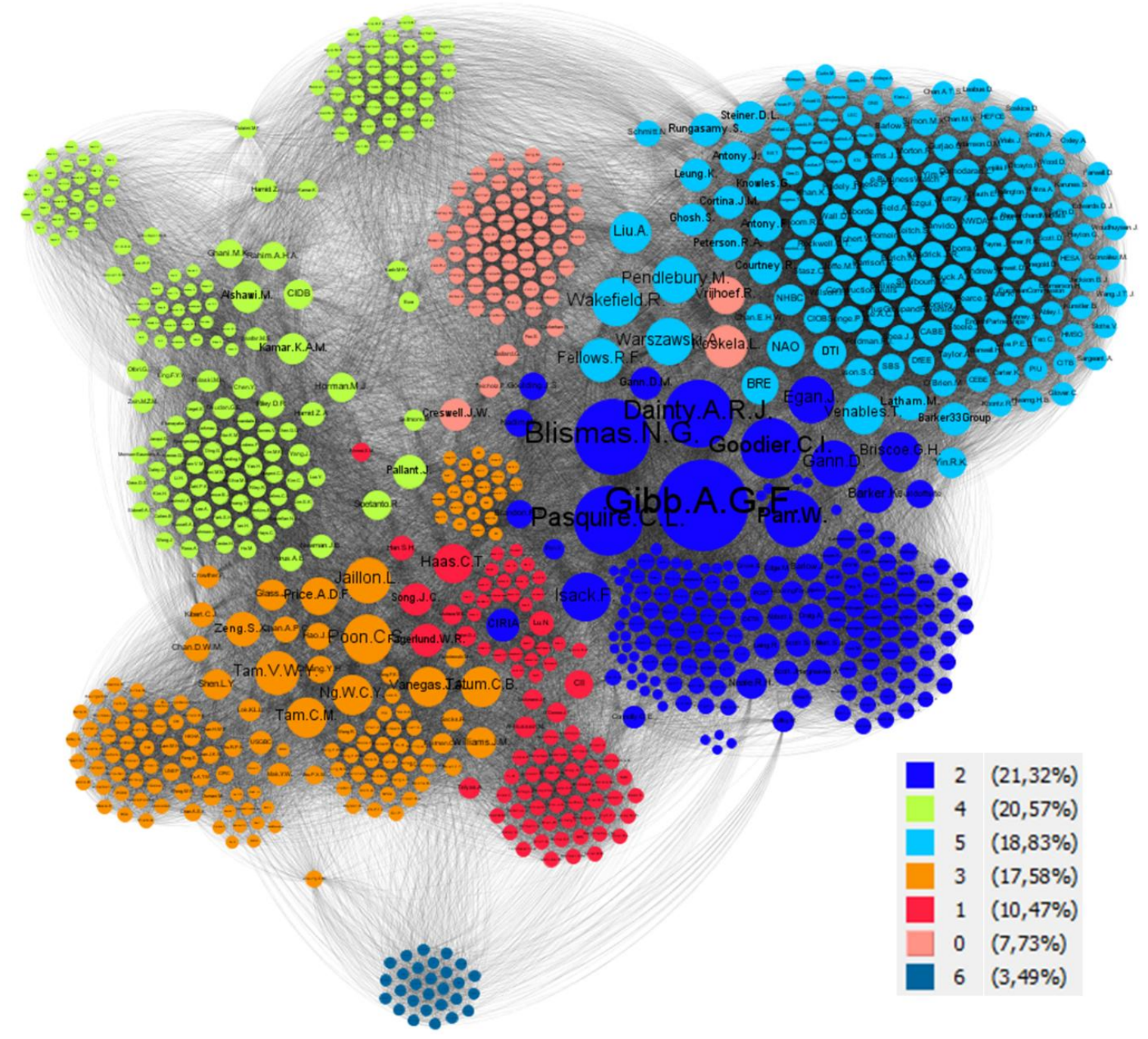


Table 4 - Journal metrics

\begin{tabular}{|c|c|c|c|c|c|c|c|c|c|c|}
\hline $\begin{array}{l}\text { Journal Title } \\
\text { Abbreviation }\end{array}$ & $\begin{array}{c}\text { Count } \\
\text { of } \\
\text { papers }\end{array}$ & $\begin{array}{c}\text { CiteScore } \\
2017\end{array}$ & $\begin{array}{c}\text { Highest } \\
\text { CiteScore } \\
\text { Percentile }\end{array}$ & $\begin{array}{c}\text { Citations } \\
2017\end{array}$ & $\begin{array}{c}\text { Documents } \\
\text { 2014-16 }\end{array}$ & $\begin{array}{c}\% \\
\text { Cited }\end{array}$ & SNIP $^{a}$ & $\begin{array}{l}\mathbf{S J R}^{\mathbf{b}} \\
2017\end{array}$ & $\begin{array}{c}\mathrm{IF}^{\mathrm{c}} \\
2017\end{array}$ & EF/AI ${ }^{d}$ \\
\hline Build Environ & 1 & 5.22 & 99 & 5.934 & 1.137 & 90 & 2.534 & 2.169 & 4.539 & $91 / 72$ \\
\hline Automat Constr & 1 & 5.36 & 99 & 2.792 & 521 & 86 & 2.568 & 1.613 & 4.032 & $77 / 60$ \\
\hline Waste Manage & 1 & 4.94 & 87 & 6.201 & 1.255 & 88 & 2.059 & 1.456 & 4.723 & $91 / 74$ \\
\hline Build Res Inf & 2 & 2.97 & 89 & 561 & 189 & 78 & 1.805 & 1.141 & 3.468 & $60 / 74$ \\
\hline J Manage Eng & 1 & 2,79 & 92 & 812 & 291 & 74 & 1.696 & 1.233 & 2.282 & $38 / 40$ \\
\hline $\begin{array}{l}\text { J Constr Eng M } \\
\text { ASCE }\end{array}$ & 1 & 2,36 & 90 & 1.027 & 436 & 77 & 1.488 & 1.023 & 2.201 & $67 / 39$ \\
\hline $\begin{array}{l}\text { Construct } \\
\text { Innovat }\end{array}$ & 2 & 2,12 & 94 & 161 & 76 & 74 & 0.987 & 0.731 & & \\
\hline $\begin{array}{l}\text { Architect Eng } \\
\text { Des Manag }\end{array}$ & 2 & 1.99 & 93 & 151 & 76 & 62 & 1.438 & 0.727 & & \\
\hline $\begin{array}{l}\text { Eng Construct } \\
\text { Architect } \\
\text { Manag }\end{array}$ & 2 & 1.9 & 92 & 226 & 119 & 66 & 1.143 & 0.653 & 1.613 & \\
\hline $\begin{array}{l}\text { Construct } \\
\text { Manag Econ }\end{array}$ & 5 & 1.66 & 74 & 378 & 228 & 57 & 1.025 & 0.816 & & \\
\hline AJCEB & 1 & 0.96 & 59 & 81 & 84 & 49 & 0.625 & 0.379 & & \\
\hline J Architect Eng & 1 & 0.82 & 96 & 79 & 96 & 48 & 0.640 & 0.284 & & \\
\hline $\begin{array}{l}\text { Int J Construct } \\
\text { Educ Res }\end{array}$ & 2 & 0.68 & 47 & 48 & 71 & 39 & 0.906 & 0.407 & & \\
\hline JESTEC & 1 & 0.57 & 48 & 307 & 535 & 33 & 0.654 & 0.193 & & \\
\hline J Eng Appl Sci & 1 & 0.37 & 32 & 1.679 & 4.489 & 22 & 0.473 & 0.189 & & \\
\hline
\end{tabular}

Note: ${ }^{a}$ SNIP = Source Normalized Impact per Paper;

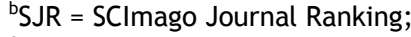

${ }^{\mathrm{C}} \mathrm{IF}=$ Impact Factor; and

${ }^{\mathrm{d}} \mathrm{EF}=$ Eingenfactor $/ \mathrm{Al}=$ Article Influence.

\section{Content review}

In addition to different survey methods, some studies were also complemented by interviews, workshops, and/or case studies. As indicated in Table 5, five studies were responsible for ten published papers. In such cases, different aspects were explored, as collected in the same research, presented pre-studies, or similar results with distinct approaches. Seven of nineteen studies focused solely on questionnaire survey. Interviews were the main complementary method $(42.1 \%)$, followed by workshops $(31.6 \%)$ and case studies (14.3\%). Only the research conducted by Gibb and Isack $(2001,2003)$ gathered all four methods.

Except for Gibb and Isack (2001, 2003), Blismas and Wakefield (2009), and O'Connor, O'Brien and Choi (2014), who had their structured questions asked directly during workshops or interviews, all questionnaires were sent to larger samples of previously selected stakeholders. The average response rate was $26.8 \%$, and the response rate ranged from $6.6 \%$ to $58.9 \%$, which corresponded to the biggest $(6,886)$ and smallest $(56)$ sample sizes, respectively. In general, approximately 12,000 questionnaires were sent (over half of them were due to the Malaysian study by Majid et al. (2011)) and 1,625 answers were received (Table 6).

Regarding benefits and barriers, the latter appeared more often in the reviewed papers, with a total of 238 indexes gathered into 156 factors, and with 15 papers evaluating perceptions by the Likert scale; whereas the former registered 99 indexes, 77 factors, and 9 papers. These numbers reflected a deeper academic interest in barriers, which agrees with the observations described by Blismas et al. (2005), that is, the industry players are familiar with OSC benefits, and using these benefits while combining them with the less known barriers and constraints may lead to different promising strategic approaches.

356 Senger, E. W.; Santos, A. de P. L.; Marques, M. A. M.; Scheer, S. 
Table 5- Reviewed paper's methodology

\begin{tabular}{|c|c|c|c|c|}
\hline Paper & Interview & Case study & Workshop & Questionnaire \\
\hline $\begin{array}{l}\text { Blismas and Wakefield (2009) and Gibb and } \\
\text { Isack (2003) }\end{array}$ & $\mathrm{X}$ & $\mathrm{X}$ & $\mathrm{X}$ & $\mathrm{X}$ \\
\hline Jaillon and Poon $(2009,2010)^{\mathrm{a}}$ & $\mathrm{X}$ & $\mathrm{X}$ & & $\mathrm{X}$ \\
\hline Lu and Liska (2008) & $\mathrm{X}$ & $\mathrm{X}$ & & $\mathrm{X}$ \\
\hline Azhar, Lukkad and Ahmad (2013) & $\mathrm{X}$ & & $\mathrm{X}$ & $\mathrm{X}$ \\
\hline Pan, Gibb and Dainty $(2007,2008)^{\mathrm{a}}$ & $\mathrm{X}$ & & & $\mathrm{X}$ \\
\hline Chen, Okudan and Riley (2010b) & $\mathrm{X}$ & & & $\mathrm{X}$ \\
\hline Gibb and Isack $(2001,2003)^{\mathrm{a}}$ & $\mathrm{X}$ & & & $\mathrm{X}$ \\
\hline Majid et al.(2011) & $\mathrm{X}$ & & & $\mathrm{X}$ \\
\hline $\begin{array}{l}\text { Blismas, Gibb and Pasquire (2005) and Blismas } \\
\text { et al. }(2005)^{\mathrm{a}}\end{array}$ & & & $\mathrm{X}$ & $\mathrm{X}$ \\
\hline $\mathrm{O}^{\prime}$ Connor, O’Brien and Choi (2014) ${ }^{\mathrm{b}}$ & & & $\mathrm{X}$ & $\mathrm{X}$ \\
\hline Goodier and Gibb (2007) & & & $\mathrm{X}$ & $\mathrm{X}$ \\
\hline Larsson et al. (2014) & & & $\mathrm{X}$ & $\mathrm{X}$ \\
\hline Sadafi, Zain and Jamil (2012) & & & & $\mathrm{X}$ \\
\hline Rahman (2014) & & & & $\mathrm{X}$ \\
\hline Yunus et al. (2016) & & & & $\mathrm{X}$ \\
\hline Zhai, Reed and Mills (2013) & & & & $\mathrm{X}$ \\
\hline Nadim and Goulding $(2009,2010)^{\mathrm{a}}$ & & & & $\mathrm{X}$ \\
\hline Tam et al. (2007) & & & & $\mathrm{X}$ \\
\hline Yunus and Yang (2012) & & & & $\mathrm{X}$ \\
\hline
\end{tabular}

Table 6- Questionnaire samples

\begin{tabular}{|c|c|c|c|c|}
\hline Paper & $\begin{array}{c}\text { Sample } \\
\text { size }\end{array}$ & $\begin{array}{l}\text { Responses } \\
\text { per paper }\end{array}$ & $\begin{array}{c}\text { Response } \\
\text { rate }(\%)\end{array}$ & Country \\
\hline Blismas and Wakefield (2009) $^{\mathrm{d}}$ & & & & Australia \\
\hline Rahman $(2014)^{b}$ & 600 & 113 & 18.8 & \multirow{4}{*}{ China } \\
\hline $\begin{array}{l}\text { Jaillon and Poon }(2010)^{\mathrm{a}} \text { and Jaillon, Poon and Chiang } \\
(2009)^{\mathrm{a}}\end{array}$ & 354 & 84 & 23.7 & \\
\hline Zhai, Reed and Mills (2013) & 298 & 110 & 36.9 & \\
\hline Tam et al. (2007) & 200 & 70 & 35.0 & \\
\hline Sadafi, Zain and Jamil (2012) & 237 & 54 & 22.8 & \multirow{4}{*}{ Malaysia } \\
\hline Yunus et al. 2016 & 150 & 54 & 36.0 & \\
\hline Yunus and Yang (2012) & 300 & 115 & 38.3 & \\
\hline Majid et al. (2011) & 6,886 & 454 & 6.6 & \\
\hline Larsson et al. (2014) & 56 & 33 & 58,9 & Sweden \\
\hline $\begin{array}{l}\text { Blismas, Gibb and Pasquire (2005) and Blismas et al. } \\
(2005)^{\mathrm{a}}\end{array}$ & 289 & 73 & 25,3 & \multirow{6}{*}{ UK } \\
\hline $\operatorname{Rahman}(2014)^{\mathrm{b}}$ & 400 & 47 & 11.8 & \\
\hline Goodier and Gibb (2007) ${ }^{\mathrm{c}}$ & & & & \\
\hline Pan, Gibb and Dainty $(2007,2008)^{\mathrm{a}}$ & 100 & 36 & 36.0 & \\
\hline Nadim and Goulding $(2009,2010)^{\mathrm{a}}$ & 247 & 56 & 22.7 & \\
\hline Gibb and Isack $(2001,2003)^{\mathrm{a}, \mathrm{d}}$ & & & & \\
\hline Azhar, Lukkad and Ahmad (2013) & 110 & 25 & 22.7 & \multirow{4}{*}{ USA } \\
\hline Lu and Liska (2008) & 1,200 & 131 & 10.9 & \\
\hline Chen, Okudan and Riley (2010b) & 412 & 95 & 23.1 & \\
\hline O'Connor, O'Brien and Choi (2014) ${ }^{\mathrm{d}}$ & & & & \\
\hline TOTAL & 11,839 & 1,625 & Ave. $26.8 \%$ & \\
\hline
\end{tabular}


The benefits/drivers were divided into nine categories:
(a) $\operatorname{cost}(\mathrm{CO})$;
(b) design (DE);
(c) $\mathrm{H} \& \mathrm{~S}$ (HS);
(d) process (PR);
(e) quality (QL);
(f) skills (SK);
(g) sustainability (ST);
(h) time $(\mathrm{T})$; and
(i) others (OT).

The average of all indexes was 3.95, which may infer a high level of agreement between participants. One may notice that Yunus et al. (2016) contributed a large sample of 36 factors, with all of them above 4 using the Likert scale, and the mean dropped to 3.79 without the Likert scale. In their study, a larger sample of 62 factors was used initially, but only the most relevant ones were presented in their paper (Table 7).

Table 7 - Reviewed benefits and drivers, Cluster 1 (Continues...)

\begin{tabular}{|c|c|c|c|c|c|c|c|c|c|c|c|c|}
\hline $\begin{array}{c}\text { BENEFITS / } \\
\text { DRIVER }\end{array}$ & 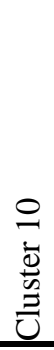 & 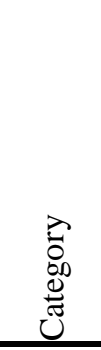 & 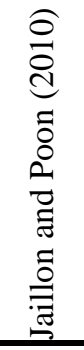 & 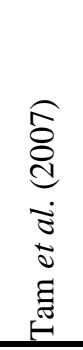 & 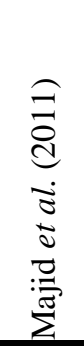 & 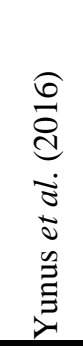 & 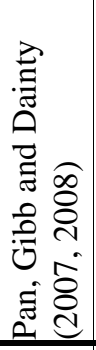 & 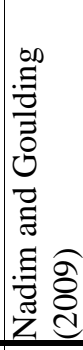 & 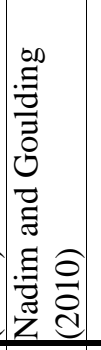 & 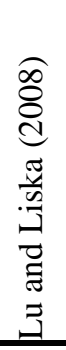 & $\sum^{\Xi}$ & $\stackrel{\Xi}{\Xi}$ \\
\hline $\begin{array}{l}\text { Reduction cost for } \\
\text { material disposal }\end{array}$ & 1 & CO1 & & & & 4.41 & & & & & 4.41 & 1 \\
\hline $\begin{array}{l}\text { Reduction cost for } \\
\text { site clearing }\end{array}$ & 1 & $\mathrm{CO} 2$ & & & & 4.39 & & & & & 4.39 & 1 \\
\hline Cost certainty & 1 & $\mathrm{CO} 3$ & & & & 4.26 & 4.40 & & & & 4.33 & 2 \\
\hline Reduction labor cost & 1 & $\mathrm{CO} 4$ & & & & 4.15 & & & & & 4.15 & 1 \\
\hline $\begin{array}{l}\text { Material cost } \\
\text { minimization }\end{array}$ & 1 & $\mathrm{CO5}$ & & & & 4.11 & & & & & 4.11 & 1 \\
\hline $\begin{array}{l}\text { Frozen design at the } \\
\text { early design for } \\
\text { better adoption of } \\
\text { prefab. }\end{array}$ & 1 & DE1 & & 4.46 & & & & & & & 4.46 & 1 \\
\hline $\begin{array}{l}\text { Higher design } \\
\text { quality }\end{array}$ & 1 & DE2 & & & & 4.19 & & & & & 4.19 & 1 \\
\hline Reducing H\&S risks & 1 & HS1 & & & & & 4.45 & & & & 4.45 & 1 \\
\hline Cleaner environment & 1 & HS10 & & & 4.10 & & & & & & 4.10 & 1 \\
\hline $\begin{array}{l}\text { Less disturbance to } \\
\text { public }\end{array}$ & 1 & HS11 & & & & 4.09 & & & & & 4.09 & 1 \\
\hline Improved H\&S & 1 & HS12 & 4.00 & & & & & & & & 4.00 & 1 \\
\hline $\begin{array}{l}\text { Easier safety } \\
\text { management }\end{array}$ & 1 & HS2 & & & & 4.44 & & & & & 4.44 & 1 \\
\hline $\begin{array}{l}\text { Safe installation for } \\
\text { IBS components }\end{array}$ & 1 & HS3 & & & & 4.44 & & & & & 4.44 & 1 \\
\hline $\begin{array}{l}\text { Clean and organized } \\
\text { site layout }\end{array}$ & 1 & HS4 & & & & 4.37 & & & & & 4.37 & 1 \\
\hline $\begin{array}{l}\text { Dust reduction on } \\
\text { site }\end{array}$ & 1 & HS5 & & & & 4.24 & & & & & 4.24 & 1 \\
\hline
\end{tabular}


Table 7 - Reviewed benefits and drivers, Cluster 1 (continued...)

\begin{tabular}{|c|c|c|c|c|c|c|c|c|c|c|c|c|}
\hline $\begin{array}{l}\text { BENEFITS / } \\
\text { DRIVER }\end{array}$ & 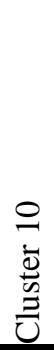 & 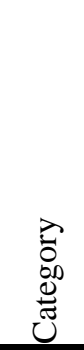 & 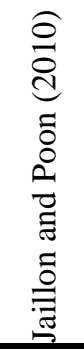 & 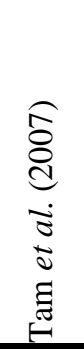 & 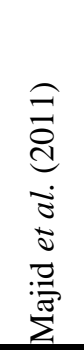 & 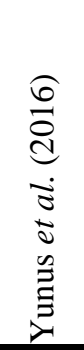 & 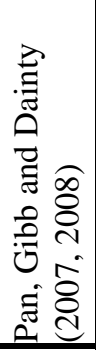 & 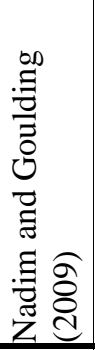 & 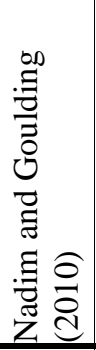 & 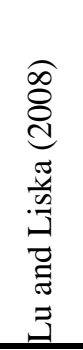 & $\sum_{\Sigma}^{\mathbb{E}}$ & 苞 \\
\hline $\begin{array}{l}\text { Higher safety for } \\
\text { workers during } \\
\text { operations }\end{array}$ & 1 & HS6 & & & & 4.22 & & & & & 4.22 & 1 \\
\hline $\begin{array}{l}\text { Good environment } \\
\text { and comfortable }\end{array}$ & 1 & HS7 & & & & 4.20 & & & & & 4.20 & 1 \\
\hline $\begin{array}{l}\text { Healthy working } \\
\text { environment }\end{array}$ & 1 & HS8 & & & & 4.20 & & & & & 4.20 & 1 \\
\hline $\begin{array}{l}\text { Improve workers' } \\
\text { quality lifestyle }\end{array}$ & 1 & HS9 & & & & 4.11 & & & & & 4.11 & 1 \\
\hline $\begin{array}{l}\text { Revisions to building } \\
\text { regulations }\end{array}$ & 1 & OT1 & & & & & 4.25 & & & & 4.25 & 1 \\
\hline $\begin{array}{l}\text { As part of company } \\
\text { strategy }\end{array}$ & 1 & OT2 & & & & & 4.10 & & & & 4.10 & 1 \\
\hline $\begin{array}{l}\text { Acceptance of IBS } \\
\text { implementation }\end{array}$ & 1 & OT3 & & & & 4.09 & & & & & 4.09 & 1 \\
\hline Buildability & 1 & PR1 & & & & 4.44 & & & & & 4.44 & 1 \\
\hline $\begin{array}{l}\text { Effective plant } \\
\text { management }\end{array}$ & 1 & PR2 & & & & 4.41 & & & & & 4.41 & 1 \\
\hline $\begin{array}{l}\text { Effective site layout } \\
\text { improve productivity }\end{array}$ & 1 & PR3 & & & & 4.20 & & & & & 4.20 & 1 \\
\hline $\begin{array}{l}\text { Restricted site } \\
\text { specifics }\end{array}$ & 1 & PR4 & & & & - & 4.15 & & & & 4.15 & 1 \\
\hline $\begin{array}{l}\text { Reduce components } \\
\text { and material } \\
\text { damages }\end{array}$ & 1 & PR5 & & & & 4.11 & & & & & 4.11 & 1 \\
\hline $\begin{array}{l}\text { Ease activities and } \\
\text { smooth process }\end{array}$ & 1 & PR6 & & & & 4.07 & & & & & 4.07 & 1 \\
\hline $\begin{array}{l}\text { Minimum on-site } \\
\text { space usage }\end{array}$ & 1 & PR7 & & & & 4.06 & & & & & 4.06 & 1 \\
\hline Higher durability & 1 & QL1 & & & & 4.21 & & & & & 4.21 & 1 \\
\hline $\begin{array}{l}\text { Aesthetic issues on } \\
\text { the building }\end{array}$ & 1 & QL2 & & 4.19 & & & & & & & 4.19 & 1 \\
\hline $\begin{array}{l}\text { Improved quality } \\
\text { control }\end{array}$ & 1 & QL3 & 4.04 & 4.55 & 3.97 & & & & & & 4.18 & 3 \\
\hline $\begin{array}{l}\text { Integrity on the } \\
\text { building design and } \\
\text { construction }\end{array}$ & 1 & QL4 & & 4.17 & & & & & & & 4.17 & 1 \\
\hline $\begin{array}{l}\text { Higher product } \\
\text { quality }\end{array}$ & 1 & QL5 & & & & 4.28 & 4.65 & 4.22 & 4.20 & 3.37 & 4.14 & 5 \\
\hline $\begin{array}{l}\text { Higher quality for } \\
\text { joint and installation }\end{array}$ & 1 & QL7 & & & & 4.07 & & & & & 4.07 & 1 \\
\hline $\begin{array}{l}\text { Addressing skills } \\
\text { shortages }\end{array}$ & 1 & SK1 & & & & & 4.45 & & & & 4.45 & 1 \\
\hline $\begin{array}{l}\text { Reduce the } \\
\text { dependency on } \\
\text { unskilled foreign labor }\end{array}$ & 1 & SK2 & & & & 4.33 & & & & & 4.33 & 1 \\
\hline
\end{tabular}


Table 7 - Reviewed benefits and drivers, Cluster 1 (continued)

\begin{tabular}{|c|c|c|c|c|c|c|c|c|c|c|c|c|}
\hline $\begin{array}{l}\text { BENEFITS / } \\
\text { DRIVER }\end{array}$ & $\begin{array}{l}0 \\
\dot{\bar{\Delta}} \\
\stackrel{\tilde{U}}{\Xi} \\
\bar{U}\end{array}$ & 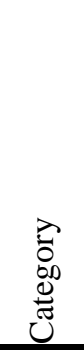 & 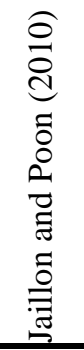 & 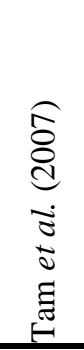 & 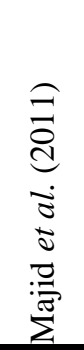 & 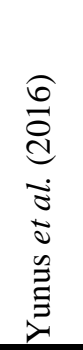 & 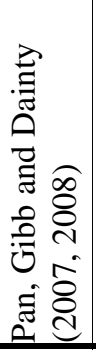 & 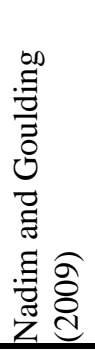 & 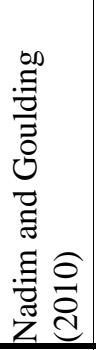 & 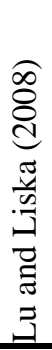 & $\sum_{\Sigma}^{\mathbb{E}}$ & $\ddot{\Xi}$ \\
\hline Skills improvement & 1 & SK3 & & & & 4.13 & & & & & 4.13 & 1 \\
\hline $\begin{array}{l}\text { Skilled workers for } \\
\text { IBS installation }\end{array}$ & 1 & SK4 & & & & 4.04 & & & & & 4.04 & 1 \\
\hline $\begin{array}{l}\text { Reduction in } \\
\text { environmental } \\
\text { pollution }\end{array}$ & 1 & ST1 & & & & 4.35 & & & & & 4.35 & 1 \\
\hline $\begin{array}{l}\text { Reduction of } \\
\text { construction waste }\end{array}$ & 1 & ST2 & 4.05 & & 4.15 & 4.32 & & 4.08 & & & 4.15 & 4 \\
\hline $\begin{array}{l}\text { Material } \\
\text { conservation }\end{array}$ & 1 & ST3 & & & & 4.13 & & & & & 4.13 & 1 \\
\hline $\begin{array}{l}\text { Reuse components } \\
\text { and materials }\end{array}$ & 1 & ST4 & & & & 4.09 & & & & & 4.09 & 1 \\
\hline $\begin{array}{l}\text { Maximizing } \\
\text { environmental } \\
\text { performance } \\
\text { throughout the } \\
\text { lifecycle }\end{array}$ & 1 & ST5 & & & & & 4.00 & & & & 4.00 & 1 \\
\hline $\begin{array}{l}\text { Minimizing on-site } \\
\text { duration }\end{array}$ & 1 & $\mathrm{~T} 1$ & & & & & 4.60 & & & & 4.60 & 1 \\
\hline $\begin{array}{l}\text { OSP used to reduce } \\
\text { time }\end{array}$ & 1 & $\mathrm{~T} 2$ & & & & & & & 4.45 & & 4.45 & 1 \\
\hline Time certainty & 1 & T3 & & & & 4.19 & 4.50 & & & & 4.35 & 2 \\
\hline $\begin{array}{l}\text { Reduction of } \\
\text { construction time }\end{array}$ & 1 & $\mathrm{~T} 4$ & 3.75 & 4.25 & 3.94 & 4.46 & & & & & 4.10 & 4 \\
\hline $\begin{array}{l}\text { OSP added value: } \\
\text { meeting deadline }\end{array}$ & 1 & T5 & & & & & & 4.06 & & & 4.06 & 1 \\
\hline $\begin{array}{l}\text { Faster delivery to } \\
\text { construction site }\end{array}$ & 1 & T6 & & & & 4.02 & & & & & 4.02 & 1 \\
\hline
\end{tabular}

After running the analysis with several pre-defined clusters, 10 was found to be an adequate size for both benefits and barriers. Table 7 lists all the benefits and drivers pertaining to Cluster 1, which had the greatest scores and the biggest set of factors. The remaining 9 clusters were rather small, with no more than 8 factors, compared to 50 factors in Cluster 1. In terms of quality, two factors were positively evaluated in more than one paper: the "higher product quality," which was cited five times with a mean value of 4.14; and the "improved quality control," with three citations and an average of 4.18. Both the "reduction of construction waste" (4.15) and "reduction of construction time" (4.10) were considered in four studies. The highest mean value of 4.60 was obtained in the British studies of Pan, Gibb and Dainty (2007; 2008); it was also related to time, with a slight variation in text: "minimizing on-site duration.". HS was found with the most identified factors (12), followed by PR (7), T (6), and QL (6). Design factors were the least frequent ones (2), and attentions should be given to the highly scored (4.46) "frozen design at the early design for better adoption of prefabrication" factor by Tam et al. (2007). As will be discussed, such a factor was one of the leading barriers/constraints of the reviewed papers and even in Tam's paper, the most significant "hindrance to applying prefabrication" was "inflexible for design changes" (4.31). The factor was considered advantageous by the authors, and they might be interpreted as a critical factor for success by the respondents and thus, eliminating the exposed ambiguity.

The barriers/constraints were divided into 11 categories: 
(a) contractual relationship (CR);

(b) culture/acceptability (CA);

(c) legal/government (LG);

(d) management-related (MR);

(e) planning-design (PD);

(f) process (PR);

(g) procurement-cost (PC);

(h) quality (QL);

(i) skills-knowledge (SK);

(j) supply chain (SC); and

(k) others (OT).

The average of all indexes was 3.6.

In contrast to the benefit analysis, Table 8 shows that the most relevant clusters for barriers, that is, those with higher mean values, were more dispersed. Three clusters $(1,2$, and 7$)$ and their factors/indexes are listed in the table, including 31 factors with 48 indexes. Two larger clusters were identified: Cluster 5 contained 62 factors and 92 indexes, with an average of 3.43, and the mean-values ranging from 3.23 to 3.60; and Cluster 6 consisted of 34 factors and 64 indexes, with an average of 3.78 and the mean-values ranging from 3.64 to 3.91 . The remaining clusters presented 29 factors with mean values closer to neutrality. The fact that the high percentile $(82.7 \%)$ of factors averaged below 4 may infer:

(a) lacking consensus from participants; and

(b) barriers were not highly relevant.

For Clusters 1, 2, and 7 in Table 8, the "higher initial cost to traditional approach" (3.96) and "inflexible/not suitable for late design changes" (3.95) were addressed repeatedlyby eight and seven papers, respectively, showing oscillating indexes ranging from 1.0 for the latter to 0.7 for the former, with no correlation found for the country of the conducted research. Another factor that was fully related to design changes was the "unable to freeze design and specification early" (4.10) that received the other three evaluations. The most frequent factor categories were: PC (7), PD (7), PR (6), CA (5), and SK (4), meaning that most barriers were related to the initial decision-making phase, not to its process. Therefore, it is necessary to develop new decision-making tools and guidelines, and keep updating and adapting the existing ones for OSC techniques.

\section{Conclusions}

Stakeholders often decide the adopted building technique and therefore, play a vital role in the implementation of OSC techniques with their manifold experiences, which are empirical but valuable source of information. As a result, stakeholder perceptions are extensively studied to assist in the development of new strategic approaches for the decision-making process. In this study, we discussed these studies in detail, especially those that quantified perceptions using the Likert scale. In total, 24 reviewed papers were obtained using the systematic review approach coupled with the snowball sampling technique. Then, both their bibliometrics and content were investigated.

The UK and the USA were found to publish most papers in the reviewed research stream, although many researchers were affiliated in countries such as China, Malaysia, and Australia. The UK was the precursor and the only country to survey stakeholder perceptions for 6 years, according to the reviewed patterns. Three years after the first publication in 2001, the dissemination of the issue has faced a fast dissemination pace of $56 \%$ new citations each year. The relevance of the reviewed papers was also assessed by author-level bibliometrics. A few highly rated (h-index) authors accounted for a considerable share of the total authors/entities cited in the reviewed sample. By analyzing the co-citation network formed by the 24 papers, the communities were visually identified with links both inside and between communities, and with a high probability for a given author to have links between all the co-cited authors. 
Table 8 - Reviewed barriers and constraints, Clusters 1, 2, and 7

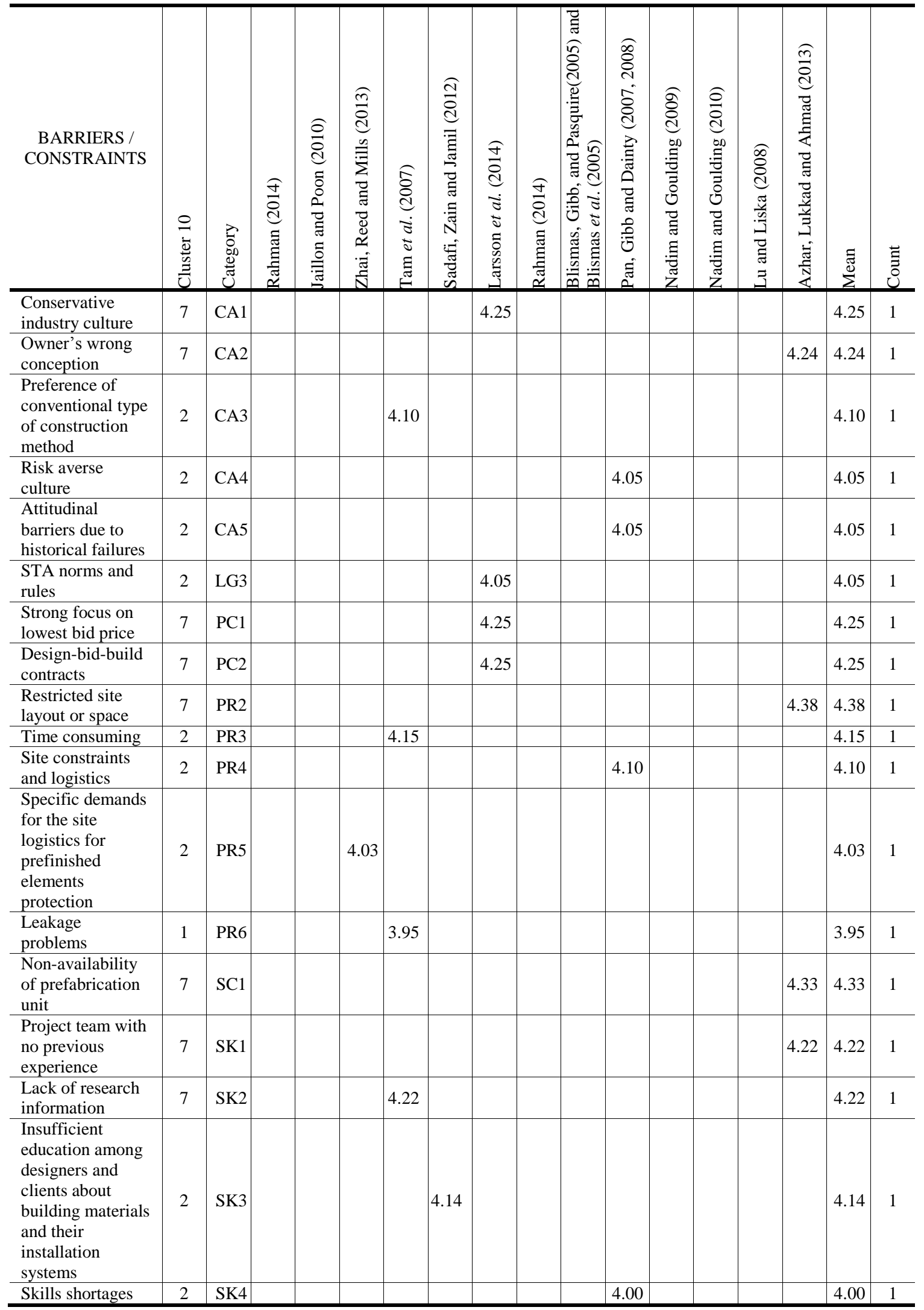

362 Senger, E. W.; Santos, A. de P. L.; Marques, M. A. M.; Scheer, S. 
In addition to surveying questionnaires, some studies also conducted interviews, workshops, and/or case studies. Thousands of questionnaires were sent, since most studies considered the representative samples of a few hundred participants, and their average response rate was $26.8 \%$. The computed Likert scale-based responses (indexes) were tabulated according to their positive or negative (barriers and benefits) connotations, and were calibrated to allow further statistical processing and interpretation.

Factors were grouped into ten clusters of barriers and ten clusters of benefits by the clustering analysis, and the most representative clusters were organized and presented in two tables. Benefits proved to be less discussed in the literature and showed greater agreement among participants. In turn, the barriers of the main clusters were close to neutrality, which may infer that there was a lack of consensus among participants or the most cited barriers were insignificant.

The results of this study can provide a small glimpse into the infinity of interpretations and assimilations that one may create while reaching for the generated and summarized data. With the knowledge of the extent and potential of the reviewed information, we deliberately coupled the bibliometrics and specific content in a single study to provide a means of comparing the desired information while counting the backup data for the impact of each study. We hope this study can help simplify the development of new strategies and decisionmaking tools, and provide guidelines for a proper implementation of OSC methods.

\section{References}

AZHAR, S.; LUKKAD, M. Y.; AHMAD, I. An investigation of critical factors and constraints for selecting modular construction over conventional stick-built technique. International Journal of Construction Education and Research, v. 9, n. 3, p. 203-225, 2013.

BABBIE, E. Survey research methods. $2^{\text {nd. }}$ ed. Belo Horizonte: UFMG, 1999.

BIKITSHA, L. The impact of prefabrication and pre-assembly on construction health and safety in South Africa. Cape Town, 2010.144 f. Dissertation (Master of technology: construction management) Cape Peninsula University of Technology, Cape Town, 2010.

BLISMAS, N. G. et al. Constraints to the use of offsite production on construction projects. Architectural Engineering and Design Management, v. 1, n. 3, p. 153-162, 2005.

BLISMAS, N. G.; GIBB, A. G. F.; PASQUIRE, C. L. Assessing project suitability for off-site production. Australasian Journal of Construction Economics and Building, v. 5, n. 1, p. 9-15, 2005.

BLISMAS, N. G.; WAKEFIELD, R. Drivers, constraints and the future of offsite manufacture in Australia. Construction Innovation, v. 9, n. 1, p. 72-83, 2009.

BLONDEL, V. D. et al. Fast unfolding of communities in large networks. Journal of Statistical Mechanics: Theory and Experiment, v. 10, 2008.

BORNMANN, L. et al. Diversity, value and limitations of the journal impact factor and alternative metrics. Rheumatology International, v. 32, n. 7, p. 1861-1867, 2011.

CANTÍN, M.; MUÑOZ, M.; ROA, I. Comparison between impact factor, eigen factor score, and scimago journal rank indicator in anatomy and morphology journals. International Journal of Morphology, v. 33, n. 3, p. 1183-1188, 2015.

CHEN, Y.; OKUDAN, G. E.; RILEY, D. R. Decision support for construction method selection in concrete buildings: prefabrication adoption and optimization. Automation in Construction, v. 19, n. 6, p. 665-675, 2010a.

CHEN, Y.; OKUDAN, G. E.; RILEY, D. R. Sustainable performance criteria for construction method selection in concrete buildings. Automation in Construction, v. 19, n. 2, p. 235-244, 2010 b.

CONSTRUCTION INDUSTRY DEVELOPMENT BOARD. Manual for IBS content scoring system (IBS score). Kuala Lumpur, 2010.

CONSTRUCTION INDUSTRY INSTITUTE. Development of a decision-support tool for prefabrication, preassembly, modularization, and offsite fabrication. Austin: University of Texas, $2002 b$.

CONSTRUCTION INDUSTRY INSTITUTE. Preliminary research on prefabrication, pre-assembly, modularization and offsite fabrication in construction. Austin: University of Texas, 2002a. 
CZARNECKI, L.; KAŹMIERKOWSKI, M. P.; ROGALSKI, A. Doing Hirsch proud; shaping h-index in engineering sciences. Bulletin of the Polish Academy of Sciences: Technical Sciences, v. 61, n. 1, 2013.

EGAN, J. Rethinking Construction: the report of the construction task force to the deputy prime minister, John Prescott, on the scope for improving the quality and efficiency of UK construction. London: Department of the Environment, Transport and the Regions (DETR), 1998.

EL-ABIDI, K. M.; GHAZALI, F. E. Motivations and limitations of prefabricated building: an overview. Applied Mechanics and Materials, v. 802, p. 668-675, 2015.

FALAGAS, M. E. et al. Comparison of SCImago journal rank indicator with journal impact factor. The FASEB Journal, v. 22, n. 8, p. 2623-2628, 2008.

FRAGIACOMO, M.; LUKASZEWSKA, E. Time-dependent behaviour of timber-concrete composite floors with prefabricated concrete slabs. Engineering Structures, v. 52, p. 687-696, 2013.

GIBB, A. G. F. Client's guide and tool kit for standardisation and pre-assembly.London: Construction Industry Research and Information Association, 2000.

GIBB, A. G. F. Offsite fabrication: prefabrication, pre-assembly and modularisation. Scotland: Whittles Publishing, 1999.

GIBB, A. G. F.; ISACK, F. Client drivers for construction projects: implications for standardization. Engineering, Construction and Architectural Management, v. 8, n. 1, p. 46-58, 2001.

GIBB, A. G. F.; ISACK, F. Future opportunities for offsite in the UK. Construction Management and Economics, v. 25, n. 6, p. 585-595, 2007.

GIBB, A. G. F.; ISACK, F. Re-engineering through pre-assembly: client expectations and drivers. Building Research \& Information, v. 31, n. 2, p. 146-160, 2003.

GOODIER, C. I.; GIBB, A. G. F. Barriers and opportunities for offsite in the UK. In: KAZI, A. S. (ed). HELSINKI INTERNATIONAL JOINT SYMPOSIUM SYSTEMATIC INNOVATION IN THE MANAGEMENT OF PROJECT AND PROCESSES, Helsinki, 2005. Proceedings [...] Helsinki, 2005.

GOODIER, C. I.; GIBB, A. G. F. Future opportunities for offsite in the UK. Construction Management and Economics, v. 25, n. 6, p. 585-595, 2007.

GOODMAN, L. A. Snowball sampling. Annals of Mathematical Statistics, v. 32, n. 1, p. 148-170, 1961.

HAIR, J. F. et al. Multivariate data analysis. $5^{\text {th }}$. ed. Prentice Hall, 1998.

HIRSCH, J. E. An index to quantify an individual's scientific research output. Proceedings of the National Academy of Sciences, v. 102, n. 46, p. 16569-16572, 2005.

JACOMY, M. et al. ForceAtlas2, a continuous graph layout algorithm for handy network visualization designed for the Gephi software. PLOS ONE, v. 9, n. 6, p. 1-12, 2014.

JAILLON, L.; POON, C. Design issues of using prefabrication in Hong Kong building construction.Construction Management and Economics, v. 28, n. 10, p. 1025-1042, 2010.

JAILLON, L.; POON, C. S. Life cycle design and prefabrication in buildings: a review and case studies in Hong Kong. Automation in Construction, v. 39, p. 195-202, 2014.

JAILLON, L.; POON, C. S.; CHIANG, Y. H. Quantifying the waste reduction potential of using prefabrication in building construction in Hong Kong. Waste Management, v. 29, n. 1, p. 309-320, 2009.

KEMPTON, J.; SYMS, P. Modern methods of construction. Structural Survey, v. 27, n. 1, p. 36-45, 2009.

KHALILI, A.; CHUA, D. K. Integrated prefabrication configuration and component grouping for resource optimization of precast production. Journal of Construction Engineering and Management, v. 140, n. 2, p. $04013052,2014$.

LARSSON, J. et al. Industrialized construction in the Swedish infrastructure sector: core elements and barriers. Construction Management and Economics, v. 32, n. 1-2, p. 83-96, 2014.

LEU, S.; HWANG, S. GA-based resource-constrained flow-shop scheduling model for mixed precast production. Automation in Construction, v. 11, n. 4, p. 439-452, 2002.

LI, Z.; SHEN, G. Q.; ALSHAWI, M. Measuring the impact of prefabrication on construction waste reduction: an empirical study in China. Resources, Conservation \& Recycling, v. 91, p. 27-39, 2014.

364 Senger, E. W.; Santos, A. de P. L.; Marques, M. A. M.; Scheer, S. 
LU, N.; LISKA, R. W. Designers' and general contractors' perceptions of offsite construction techniques in the United State construction industry. International Journal of Construction Education and Research, v. 4, n. 3, p. 177-188, 2008.

LUO, Y. Decision support for prefabrication strategy selection on building systems. Pennsyvania, 2008.Thesis (Doctor) - The Pennsylvania State University, Pennsylvania, 2008.

MAJID, T. A. et al. Quantitative analysis on the level of IBS acceptance in the Malaysian construction industry. Journal of Engineering Science and Technology, v. 6, n. 2, p. 179-190, 2011.

MAO, C. et al. Comparative study of greenhouse gas emissions between offsite prefabrication and conventional construction methods: two case studies of residential projects. Energy and Buildings, v. 66, p. 165-176, 2013.

MAO, C. et al. Cost analysis for sustainable offsite construction based on a multiple-case study in China. Habitat International, v. 57, p. 215-222, 2016.

MCGRAW-HILL. Prefabrication and modularization: increasing productivity in the construction industry. Bedford: SmartMarket Report, 2011.

MCKAY, L. J. The effect of offsite construction on occupational health and safety.Loughborough, 2010.Thesis (Doctor) - Loughborough University, Loughborough, 2010.

MODULAR BUILDING INSTITUTE. Permanent modular construction: process, practice, performance. Charlottesville, 2015.

MURTAZA, M. B.; FISHER, D. J. Neuromodex - neural network system for modular construction decision making. Journal of Computing in Civil Engineering, v. 8, n. 2, p. 221-233, 1994.

MURTAZA, M. B.; FISHER, D. J.; SKIBNIEWSKI, M. J. Knowledge-based approach to modular construction decision support. Journal of Construction Engineering and Management, v. 6, n. 4, p. 285$292,1993$.

NADIM, W.; GOULDING, J. S. Offsite production in the UK: the construction industry and academia. architect. Architectural Engineering and Design Management, v. 5, n. 3, p. 136-152, 2009.

NADIM, W.; GOULDING, J. S. Offsite production in the UK: the way forward? A UK construction industry perspective. Construction Innovation, v. 10, n. 2, p. 181-202, 2010.

O'CONNOR, J. T.; O’BRIEN, W. J.; CHOI, J. O. Critical success factors and enablers for optimum and maximum industrial modularization. Journal of Construction Engineering and Management, v. 140, n. 6, p. $04014012,2014$.

PAN, W.; GIBB, A. G. F. Maintenance performance evaluation of offsite and in situ bathrooms. Construction Innovation, v. 9, n. 1, p. 7-21, 2009.

PAN, W.; GIBB, A. G. F.; DAINTY, A. R. Leading UK housebuilders utilization of offsite construction methods.Building Research \& Information, v. 36, n. 1, p. 56-67, 2008.

PAN, W.; GIBB, A. G. F.; DAINTY, A. R. Perspectives of UK housebuilders on the use of offsite modern methods of construction. Construction Management and Economics, v. 25, n. 2, p. 183-194, 2007

PAN, W.; SIDWELL, R. Demystifying the cost barriers to offsite construction in the UK. Construction Management and Economics, v. 29, n. 11, p. 1081-1099, 2011.

PENDLEBURY, M. C.; GIBB, A. G. F. Standardisation and pre-assembly: capturing clients requirements. In: CLIENTS DRIVING INNOVATION CONFERENCE, Brisbane, 2004.Proceedings [...] Brisbane, 2004.

RAHMAN, M. M. Barriers of implementing modern methods of construction. Journal of Management in Engineering, v. 30, n. 1, p. 69-77, 2014.

SADAFI, N.; ZAIN, M. F.; JAMIL, M. Adaptable industrial building system: construction industry perspective. Journal of Architectural Engineering, v. 18, n. 2, p. 140-147, 2012.

SMALL, H. Co-citation in the scientific literature: a new measure of the relationship between two documents. Journal of the American Society for Information Science, v. 24, n. 4, p. 265-269, 1973.

SONG, J. et al. Considering prework on industrial projects. Journal of Construction Engineering and Management, v. 131, n. 6, p. 723-733, 2005. 
STALLEN, M.; CHABANNES, Y.; STEINBERG, F. Potentials of prefabrication for self-help and mutualaid housing in developing countries. Habitat International, v. 18, n. 2, p. 13-39, 1994.

TAM, V. W. et al. Best practice of prefabrication implementation in the Hong Kong public and private sectors. Journal of Cleaner Production, v. 109, p. 216-231, 2015.

TAM, V. W. et al. Towards adoption of prefabrication in construction. Building and Environment, v. 42, n. 10, p. 3642-3654, 2007.

TANANBAUM, G. Article-level metrics. A SPARC Primer. Available from: http://www.sparc.arl.org/resource/sparc-article-level-metrics-primer. Access: 14 Dec. 2018.

TATUM, C. B.; VANEGAS, J. A.; WILLIAMS, J. M. Constructability improvement using prefabrication, preassembly, and modularization. Austin: Construction Industry Institute, 1987.

WOODS, M.; MACKLIN, R.; LEWIS, G. K. Researcher reflexivity: exploring the impacts of CAQDAS use. International Journal of Social Research Methodology, v. 19, n. 4, p. 385-403, 2015.

YUNUS, R. et al. Examining performance of industrialized building system (IBS) implementation based on contractor. Journal of Engineering and Applied Sciences, v. 11, n. 6, p. 3776-3782, 2016.

YUNUS, R.; YANG, J. Critical sustainability factors in industrialised building systems. Construction Innovation, v. 12, n. 4, p; 447-463, 2012.

ZHAI, X.; REED, R.; MILLS, A. Factors impeding the offsite production of housing construction in China: an investigation of current practice. Construction Management and Economics, v. 32, n. 1-2, p. 40-52, 2013.

Eduardo Werneck Senger

Programa de Pós-Graduação em Engenharia de Construção | Universidade Federal do Paraná | Av. Coronel Rua Francisco H. dos Santos, 100 | Curitiba - PR -Brasil | CEP 81531-980 | Tel.: (41) 3361-3445 | E-mail: eduardowsenger@hotmail.com

Adriana de Paula Lacerda Santos

Programa de Pós-Graduação em Engenharia de Construção | Universidade Federal do Paraná | Tel.: (41) 3361-3609 | E-mail: adrianapls@ufpr.br

Marcos Augusto Mendes Marques

Departamento de Engenharia de Produção | Universidade Federal do Paraná |Tel.: (41) 3361-3639 |E-mail: marcos.marques@ufpr.br

Sérgio Scheer

Programa de Pós-Graduação em Engenharia de Construção | Universidade Federal do Paraná | Tel.: (41) 99185-9089 | E-mail:

scheer@ufpr.br

\author{
Ambiente Construído \\ Revista da Associação Nacional de Tecnologia do Ambiente Construído \\ Av. Osvaldo Aranha, $99-3^{\circ}$ andar, Centro \\ Porto Alegre - RS - Brasil \\ CEP 90035-190 \\ Telefone: +55 (51) 3308-4084 \\ Fax: +55 (51) 3308-4054 \\ www.seer.ufrgs.br/ambienteconstruido \\ E-mail: ambienteconstruido@ufrgs.br
}

cC) 